\title{
French geneticists split over terms of commercial use of DNA bank
}

Paris. A proposed deal that would have given Millennium, a Massachusetts-based biotechnology company, exclusive access to a bank of DNA collected from over 800 French families has triggered a fierce debate in France over how efforts to sequence the human genome project should be commercialized.

The controversy centres on claims by Philippe Froguel, a researcher at the Centre d'Etudes du Polymorphisme Humain (CEPH) in Paris, that he has lost his job at the centre because of his opposition to the proposed deal. His group developed the DNA bank with samples taken from more than 5,000 individuals, and also discovered the first gene for noninsulin-dependent diabetes in 1992 (Nature, 356, 162; 1992).

Froguel says that CEPH had been about to provide Millennium with exclusive access to the bank for $\$ 400,000$ a year for four years, a relatively small fraction of his laboratory's FFr 8.2 million (US $\$ 1.8$ million) annual budget.

He also argues that Daniel Cohen, the director of CEPH, is facing a conflict of interest, as he is also both a founding scientific director and a shareholder of
Millennium. Froguel says that Millennium needs access to the bank to secure a broad alliance with the Swiss company, Hoffmann La Roche, aimed at developing drugs to treat diabetes.

But Cohen says that he has left all decisions about the proposed Millennium contract to the board of $\mathrm{CEPH}$, which includes government representatives as the centre is partly financed by the government. Mark Levin, chief executive officer of Millennium, says the deal being negotiated with Roche is a broad one, and does not depend on having access to DNA from the French families.

Cohen says that both he and the board of CEPH rejected Millennium's initial proposal on the grounds that it was inequitable, that it did not make clear the terms of CEPH's scientific participation, and that it may have violated French ethical regulations. But he says the board has told him to continue negotiations in the hope of reaching an agreement, and he has proposed that the CEPH bank be made available to users for a fee.

Froguel claims that the validity of his concerns were confirmed last week by the intervention by Alain Pompidou, scientif-

\section{Maps show gains of reduced $\mathrm{SO}_{2}$ emissions}

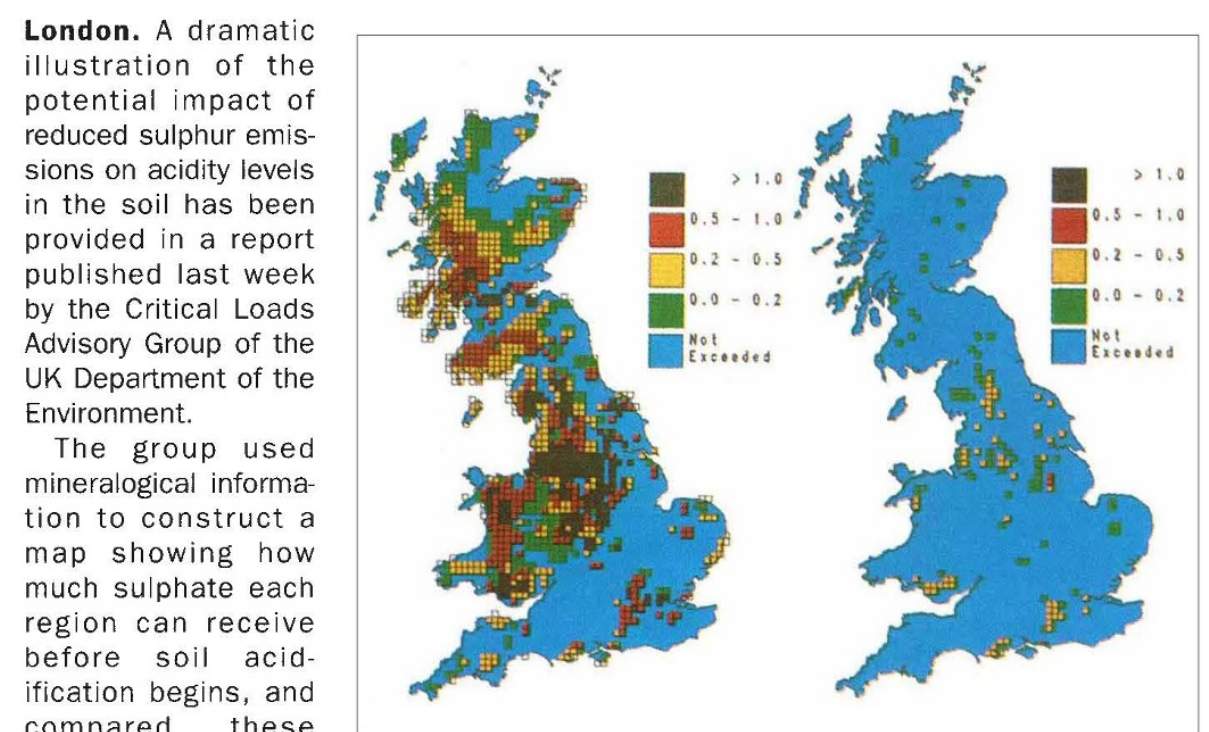

compared these values to the regional

distribution of atmospheric sulphate deposition in the period 1989-91. The result is a map (left) showing areas that receive more than the critical load of sulphate, and therefore experience acidification.

The group then used this approach to predict the likely effect of attempts to reduce industrial emissions by modelling ic adviser to the prime minister Edouard Balladur. Pompidou says that the contract under discussion between the French centre and the US company did not provide for a fair partnership. But he says the government has not blocked a deal.

The government has now set up a committee to decide how the commercial use of DNA data-banks should be regulated. Indeed, the conflict at CEPH has precipitated a broader debate on the use of information about the human genome.

Many French researchers were annoyed at the prospect that Millennium would have obtained exclusive access to the DNA bank. But one leading US genome researcher argues that companies such as Millennium have little interest in getting exclusive access to DNA banks. "It's not like a patent issue," he says. "Millennium would get a head start; it would not give them a blocking position."

He says that diabetes research requires access to DNA banks from different ethnic groups, and that companies realize that, if they start privatizing DNA banks, they will all lose. Levin says the wariness of French researchers about commercial ties is reminiscent of the early days of biotechnology in the United States.

He also points out that, as there is no open access to CEPH's bank, CEPH and the French government are already effectively exercising an exclusive licence on it. Axel Kahn, director of the INSERM laboratory of Genetics and Molecular Pathology in Paris, says that this is a general problem where research could potentially lead to important applications. A solution, he suggests, would be to oblige researchers to make their resources freely available after a reasonable period in which to exploit them themselves.

Jean-Francois Mattei, the rapporteur for three bioethics bills currently before the French Parliament, claims says that the commercial value of DNA banks had not been anticipated in drawing up current guidelines. As a result, subjects only gave their informed consent to the use of their DNA for research, not for profit.

As a result of his public dispute with Cohen, Frogeau has now been asked to leave CEPH by its president, Jean Dausset. At the same time, Bernard Barateau, president of the French Muscular Dystrophy Association, has decided to withdraw the association's FFr3 million annual funding of diabetic research at CEPH. "We are interested in DNA being freely available to researchers worldwide," says Barateau. "We have no time for such conflict."

Declan Butler 